\section{Effect of Fall Planting Date on Bulb Yield of 'Sweet Winter' Onion in the Rolling Plains of Texas}

\author{
P.A. Richwine ${ }^{1}$ \\ Texas A\&M Vegetable Research Station, Munday, TX 76371
}

Additional index words. overwintering, transplanting, winter kill, Allium cepa

Climate of the Rolling Plains of Texas allows direct seeding of-short- and intermediate-day onions (Allium cepa L.) in the fall for harvest in late spring (Nagel, 1984). Direct seeding in the fall eliminates disease risks and costs of spring 'transplanting and also allows an earlier harvest than does spring transplanting. However, direct seeding too early in the fall increases the danger of bolting, while seeding too late increases the danger of winter killing (Brewster et al., 1977; Brewster and Salter, 1980).

Planting date, through its effect on plant size, exerts a strong influence on bolting and winter killing. Onions seem to need a minimum of two to three true leaves to survive the winter, but the plants must not exceed $\approx 1 \mathrm{~cm}$ in shank diameter with four to five true leaves, or low temperatures will induce bolting (Brewster et al., 1977; Voss and Yamaguchi, 1979). The planting window for maximum survival with minimal bolting is therefore narrow.

This study was conducted to determine the effect of seeding date on yield of overwintered onions. A Miles fine sandy loam (fine loam, mixed, thermic Udic Paleustalfs) near the Research Station was prepared in early Sept. 1985 with a broadcast, preplant application of $117 \mathrm{~N}-64 \mathrm{P}-0 \mathrm{~K}\left(\mathrm{~kg} \cdot \mathrm{ha}^{-1}\right)$. Raised beds were formed on 1-m centers. A preplant incorporated application of bensulide at 6.8 kg-ha-' was made for weed control. 'Sweet Winter' onion was direct-seeded at 5.6 kg-ha-' in two drill rows per bed with 30.5 $\mathrm{cm}$ between rows. Plots were $6 \mathrm{~m}$ long. The plots were furrow-irrigated to minimize stress. onions were thinned to $\approx 75 \mathrm{~mm}$ apart in each row; and a topdressing of $56 \mathrm{~kg} \mathrm{~N} / \mathrm{ha}$ was applied in Mar. 1986.

Four planting dates in 1985 were selected to bracket reasonable fall seeding dates: 19 and 27 Sept., 4 and 11 Oct. The plantings were arranged in a randomized complete-block design with five replications.

Onions were harvested, graded, and weighed from a random $3.1 \mathrm{~m}$ of each plot on 30 May ,1986. Bulbs were counted to determine percent of stand.

The linear regression equation relating

Received for publication 13 Mar. 1989. The cost of publishing this paper was defrayed in part by the payment of page charges. Under postal regulations, this paper therefore must be hereby marked advertisement solely to indicate this fact.

'Deceased. Send requests for reprints to D.G. Bordovsky. planting date to total bulb yield (Fig. 1) was: $\mathrm{y}^{\prime}=401.83-1.39 \mathrm{x}$, where $\mathrm{y}^{\prime}=$ yield $\left(\mathrm{t} \cdot \mathrm{ha}^{-1}\right)$ and $\mathrm{x}=$ Julian date. This equation accounted for $90 \%$ of the variance in the data.

Direct-seeding onions on 19 Sept. resulted in a higher total yield than later planting dates. Delayed sowings 8 and 15 days after midSeptember resulted in an average total yield loss of $43 \%$. Seeding on 11 Oct. caused an $86 \%$ drop in total yield when compared to the 19 Sept. seeding.

Initial plant populations in this experiment were similar for all planting dates $(260,000$ plants/ha). Therefore, most of the variation in yield with respect to sowing date can be attributed to. the extent of overwintering losses.

Temperatures dropped below 0C several ' times during Nov. 1985 through Mar. 1986 (Table 1). Onions sown 11 Oct. were the most susceptible to winter conditions, with an $84 \%$ stand loss, while onions seeded 27 Sept. and 4 Oct. had an average stand loss of
42\% and those sown 19 Sept. lost only $1 \%$.

The linear relationship between yield and planting date (Fig. 1) may be used to estimate the best sowing date to obtain optimum yields. It is conceivable that the optimum planting date in the Rolling Plains may be earlier than mid-September; however, bolting may be a key factor involved with earlier sowings. Brewster and Salter (1980) have shown that earlier sowings tended to favor bolting rather than bulbing.

This study and others (Brewster et al., 1977) show the importance of planting date and its effect on yield of overwintered onions. Sowing later than mid-September resulted in lower yields primarily because of higher plant mortality. Further studies relating sowing date, bolting, yield, and year-toyear variability in climatic factors such as temperature may pinpoint. the optimum planting date for overwintering onion production in the Rolling Plains.

\section{Literature Cited}

Brewster, J. L., P.J. Salter, and R.J. Darby. 1977. Analysis-of the growth and yield of overwintered onions. J. Hort. Sci. 52:335-346.

Brewster, J.L. and P.J. Salter. 1980. The effect of plant spacing on the yield and bolting of two cultivars of overwintered bulb onions. J. Hort. Sci. 55(2):97-102.

Nagel, D.H. 1984. Fall seeded onion potential in the Rolling Plains of Texas. Texas Agr. Expt. Sta. PR-4254.

Voss, R.E. and M. Yamaguchi. 1979. Stages of growth, p. 1-6. In: R.E. Voss (ed.). Onion production in California. Univ. of California Agr. Sci. Publ., Berkley.

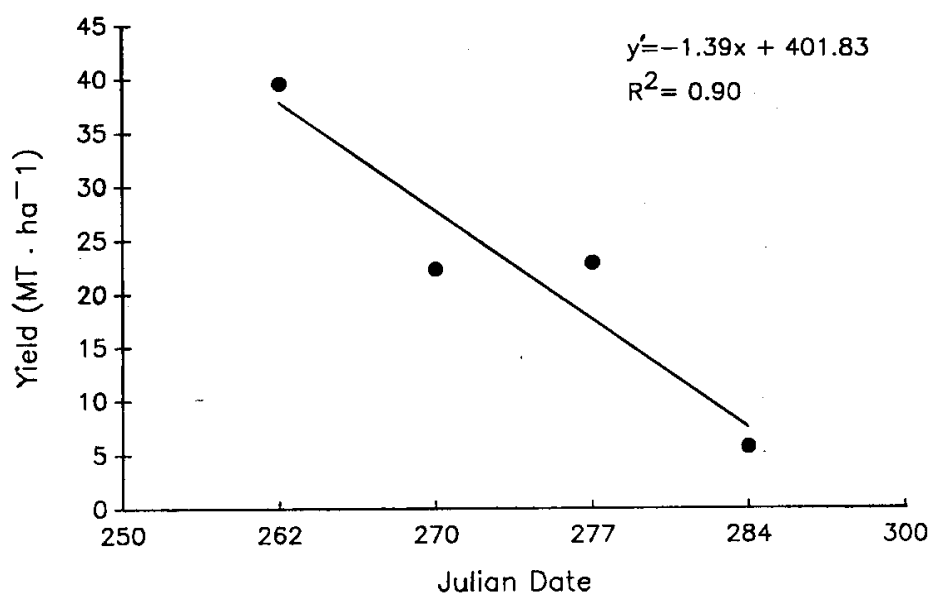

Fig. 1. Linear relationship between planting date and total bulb yield of 'Sweet Winter' onion seeded on four dates.

Table 1. Climatic data for overwintering onion planting date trial, 19 Sept. 1985 to 30 May 1986.

\begin{tabular}{|c|c|c|c|c|}
\hline \multirow{2}{*}{$\begin{array}{l}\text { Time } \\
\text { interval }\end{array}$} & \multicolumn{3}{|c|}{ Air temperature $\left({ }^{\circ} \mathrm{C}\right)$} & \multirow{2}{*}{$\begin{array}{l}\text { Precipitation } \\
(\mathrm{mm})\end{array}$} \\
\hline & High & Low & Mean & \\
\hline 19-30 Sept. 1985 & 32 & 2 & 27 & 23 \\
\hline Oct. 1985 & 30 & 3 & 17 & 74 \\
\hline Nov. 1985 & 27 & -4 & 8 & 7 \\
\hline Dec. 1985 & 24 & -12 & 2 & 1 \\
\hline Jan. 1986 & 27 & -13 & 7 & 0 \\
\hline Feb. 1986 & 26 & -14 & 10 & 29 \\
\hline Mar. 1986 & 30 & -2 & 14 & 58 \\
\hline April 1986 & 36 & 6 & 19 & 43 \\
\hline 1-30 May 1986 & 37 & 9 & 22 & 77 \\
\hline
\end{tabular}

